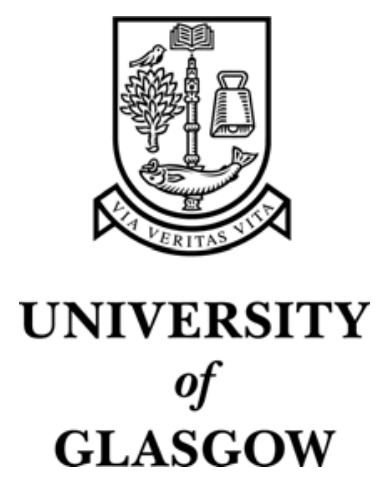

Cohen, B. L. (1992) Utility of molecular phylogenetic methods: a critique of immuno-taxonomy. Lethaia 25:pp. 441-442.

http://eprints.gla.ac.uk/2941/ 


\title{
Utility of molecular phylogenetic methods: a critique of immuno-taxonomy
}

\author{
BERNARI) L. COHEN
}

In a seminal paper that recognized informational macromolecules such as DNA as the preferred source of molecular phylogenetic data, Zuckerkandl and Pauling (1965) laid the foundation of molecular phylogenetics. Guiding principles of phylogenctic systematics have been widely recognized (Hennig 1966: Wiley 1981; Patterson 1987) and, more recently, facile methods for phylogenetic applications of DNA sequencing have been developed (Ilillis \& Moritz 1990).

Zuckerkandl and Pauling (1965) also described a class of 'episemantic' molecules (exemplified by ATP and a polysaccharide) that should not be used for phylogenetics. These -... cannot furnish the basis for a universal phylogeny for ... if universal, [ such episemantides] are not variable . . . and if vitriable, are not universal . . wrong inferences about phylogenetic relationships may be drawn from the presence of identical or similar episemantic molecules in different organisms'. Nevertheless, a recently-proposed molecular immuno-laxonomy of living and fossil brachiopods (Collins et al. 1988; Collins et al. 1991b; (urry et al. 1991) appears to be based on episemantides: closeness of phylogenetic relationship is measured by immunological distance' determined with antibodies raised against glycoproteins whose antigenic determinants are apparently 'predominantly ... carbohydrate' (Collins et al. 1991a).

Unfortunately, the phylogenetic utility of this immuno-taxonomy (given as ' . . less precise . . than sequencing' - Curry et al. 1991) only loosely describes the true value of the determinants in question, presumably because their status as episemantic molecules was not taken fully into account. Moreover, although it was recognized that immuno-taxonomy is a phenetic, not a phylogenetic method (Collins et al. 1988), discussion of the results (Collins et al. 1988; Curry et al. 1991) may be thought paradoxically to imply phylogenetic systematics.

The purpose of this note is to draw attention to the limited value of immuno-taxonomy (especially of episemantides) and to caution against according to it attributes of phylogenetic power and utility associated with sequences of genetic informational macromolecules that are true "documents of evolutionary history' (Zuckerkandl \& Pauling 1965). 
Among the defects of phylogenetic utility from which immuno-taxonomy based on episemantic molecules suffers are:

(a) Antigens similar enough to reatel with a gisen antibody are not necessarily homologous antigens, i.e. antigens controlled by homologous genes and serving homologous cellular functions. Dillerences (or similarities) expressed as immunodistance could be due to mixed and or mimic. phylogenetically independent epitopes or even to differences in antigen concentration fohell weight. not antigen quantity was standardized per reaction in (ollins a al. 1988, 1991a, b). Thus, there is mo strong basis for a test of character homology and. since homology is in doubt. phylogenetic interpretation is inapproprialle

(b) Whilst immuno-distances hased on polypepride antigens of knowable secpence divergence can be calibrated against genetic (hence evolutionary) divergence, calibration is essentially impossible with polysatcharide episemantides because the underlyng genetic variation occurs in the unamalysed genes colling for either the enzymes which attach the sugars. or the protein moiety of the glycoprotein, or both. For such episemantic antigens, immuno-distances correspond to no definable measure of genctic or evolutionary divergence: the analysis can provide only a yualiative. phenetic classification. Moreover. even with divergence-calibrated polypeptide epitopes, the "power" of immune-distance analyses (the underlying number of phỵlogenctically informative nucleotide sites in genes confrolling the varialion) is as much as two orders of magnitude lower than the power of specific gene sequencing.

(c) Maximum immunolngical distance (no cross-reaction) is indistinguishable from absence of antigen. i.e. the character is not universally present. Thus, as Zuckerkandl and Pauling (196,5) recognised, episemantic molecular characters may al most definc patts of a phylegenetic trec.

In passing. we maty mote that the dillicully of ohtaming brachiopod D)NAs has been overstaled (curry el al. |99|). In fice. phylogenctically informative DNA sequences can be recoreced from dried and alcohol-preserved brachiopods and a

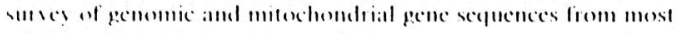
of the collectable brathoped family-level taxal is in progress (BI.C. unpublished work). For these studies, certain additional simples from muscum or personal collections will be welcomed: for information write to the atuthor.
Acknowledgments. I am grateful to several colleagues for critical reading and to a referee. Dr C. Patterson, for helpful comments. My work has been supported by the UK Natural Enviromment Research Council, the Royal Societies of London and New Zealand, the Carnegie Trust for the Universities of Scotland, the Nuflicld Foundation. the National Research Council of Canada and the University of Glasgow.

\section{References}

Collins, M. J., Curry. (i. B., Quinn. R.. Muyzer. G.. Zomerdijk. T. \& Westhrock, P. 1988: Sero-taxonomy of skeletal macromolecules in living terebratulid brachiopods. Mistorical Biology' 1. 207224.

Collins, M. J., Muyzer. (i., Curry. (j. B.. Sandberg, P. \& Westbrock, P. 1991a: Macromolecules in brachiopod shells: chatacterization and diagenesis. Idthaia 24. 387397.

Collins, M. J.. Curry, G. B.. Muyzer. G., Quinn, R., Xu, S., Westbroek. P. \& Ewing. S. 1991b: Immunological investigations of relationships within the terebratulid brachiopods. Palacemologg! 34, $785-796$.

Curry. G. B., Quinn, R., Collins. M. J.. Endo, K.. Ewing. S.. Muyzer. (i. \& Westbrock, P. 1991: Immunological responses from brachiopod skeletal macromolecules: a new technique for assessing taxonomic relationships using shells. Lethaia 24. 399407

Hennig. W. 1966 : Phylogenetic Sistematics. $439 \mathrm{pp}$. University of Illinois Press. Urbana.

Hillis D. M. \& Moritz, (. 1991: Molecular Systematics. $588 \mathrm{pp}$. Sinatuer. Mass.

Patterson. (. 1987: Introduction. In Palterson. C. (ed.): Molecules and Morpholeger in Etolutiom: Conflict or Compromisc'. I 22. (ambridge (Iniversily Press, (ambridge.

Wiley. E. O. 1981: Phylegene'tics. 439 pp. Wiley. New York.

Zuckerkandl. E. \& Pauling. L. 1965: Molecules as documents of evolutionary history. Jourmal of Theoretical Biology 8, 357 306.

Bernard L. Cohen, Genetics Deparment. C'nirersity of Glasgow.

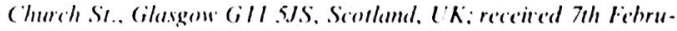
ary. 1992. revised typescript accepted I7th Jume. 1992. 